\title{
PON1 enzimi üzerine DT-15-Crown-5 taç eterinin etkisinin araştırılması
}

\author{
Adem ERGÜN ${ }^{1, *}$, Baki ÇİÇEK ${ }^{2}$ \\ ${ }^{1}$ Balıkesir Üniversitesi Bilim ve Teknoloji Uygulama ve Araştırma Merkezi, Çağış kampüsü, Balıkesir \\ ${ }^{2}$ Balıkesir Üniversitesi Fen Edebiyat Fakültesi, Çağış kampüsü, Balıkesir
}

Geliş Tarihi (Received Date): 25.09 .2019

Kabul Tarihi (Accepted Date): 19.12.2019

\section{$\ddot{O} z$}

Insan serum paraoksonaz 1 (PON1, EC3.1.8.1) HDL'ye bağll olan, aktif bölgesinde kalsiyum içeren, organofosfat ajanlarını ve sinir gazlarını hidroliz eden, LDL'nin oksidasyonu ile lipit peroksitlerin oluşumuna ve bakteri endotoksinlerine karşı koruyucu etkisi olan önemli bir karaciğer enzimidir. Çalışmamızda, PON1 enzimi daha önceden sentezi yapılmış, sepharose-4B-L-tirosin-1-naftilamin jeli kullanılarak hidrofobik etkileşim kromatografisi ile tamamen saflaştırılmıştır. Enzimin saflık kontrolü de SDSPAGE ile yapılmıştır. Inhibisyon ajanı olarak kullanılmak üzere 7,13-dithio-1,4,10trioksasiklopentadekan (DT-15-Crown-5) tiyo taç eteri $S_{N}^{2}$ mekanizmasına göre halka kapama reaksiyonu sonucunda sentezlendi. DT-15-Crown-5'in paraoksanaz enzimi üzerinde kuvvetli inhibisyon etkisi gözlendi. DT-Taçeterin PON1 ile inhibisyon değeri (IC $\left.C_{50}\right)$ 22,62 $\mu M$ olarak tespit edildi.

Anahtar kelimeler: Tiyo taç eter, paraoksanaz (PON), inhibisyon, hidrofobik etkileşim kromatografisi.

\section{Investigation of the effect of DT-15-Crown-5 crown ether on PON1 enzyme}

\begin{abstract}
Human serum paraoxonase 1 (PON1, EC3.1.8.1) is an important liver enzyme which is bound to HDL, contains calcium in its active site, hydrolyses organophosphate agents and nerve gases, has protective effect against the formation of lipid peroxides by oxidation of LDL and bacterial endotoxins. In our study, in order to purify the enzyme PON1, it was purified by hydrophobic interaction chromatography using sepharose-4B-

\footnotetext{
*Adem ERGÜN, ademergun@balikesir.edu.tr, http://orcid.org/0000-0003-4647-6058

Baki ÇIÇEK, bcicek@balikesir.edu.tr, http://orcid.org/0000-0003-1257-1188
} 
L-tyrosine-1-naphthylamine gel. The purity of the enzyme was also checked by SDS PAGE. 7,13-Dithio-1,4,10-trioxacyclopentadecane (DT-15-Crown-5) thio crown ether was synthesized as a result of the ring closure reaction according to the $S_{N}^{2}$ mechanism to be used as an inhibiting agent. Strong inhibition effect of DT-15-Crown-5 on paraoxanase enzyme was observed. Inhibition value $\left(I_{50}\right)$ of DT-Taçeter with PON1 was determined as $22.62 \mu M$.

Keywords: Thiocrown ether, paraoxanase (PON), inhibition, hydrophobic interaction chromatography.

\section{Giriş}

Lipitlerin metabolik reaksiyonlarında oldukça etkili olan paraoksonaz enzimi (PON) (E.C. 3.1.8.1.), insan plazmasında HDL (high density lipoprotein) biyomolekülüne bağlı olarak bulunur. Günümüzde sıkça rastlanan kalp-damar hastalıklarında, lipit metabolizmasındaki rolü ile büyük bir öneme sahiptir. Karaciğerde sentezlenen PON, fizyolojik fonksiyonu henüz tam olarak belirlenememiş olsa da en önemli özelliklerinden birisi de kolesterolün taşınmasında rol alan LDL'nin ve HDL'nin oksidasyonunu önlemektir. Bazı organofosfatlı bileşiklerin zehirsizleştirilmesinde de rol oynamaktadir.

Organofosfatazların memelilerin kan plazmasındaki varlığ 1 yaklaşık 80 yıl önce tespit edilmiştir [1]. Daha sonra yapılan çalışmalar bu enzimlerin paraoksonaz ve arilesteraz olduğunu göstermiştir [2]. Aldridge, ilk olarak organofosfatazları; A ve B olmak üzere iki ana grupta sınıflandırmıştır. A esterazlar organofosfat bileşiklerini hidrolizlerken, B esterazlar bu bileşikler tarafindan inhibe edilmektedir $[3,4]$. A esteraz grubunda yer alan paraoksonaz enzimi, aktivitesinin ölçümünde genellikle substrat olarak paraokson kullanıldığı için bu ismi almıştır. Paraokson organizmaya zararlı olup pestisit olarak kullanılan parationun metabolik ürünüdür [5]. Bu enzimin sistematik adı arildialkilfosfatazdır (E.C.3.1.8.1). Ayrıca aktivitesi ve kararlılığı için $\mathrm{Ca}^{+2}$ 'a bağımlı, 45-kDa moleküler ağırlığa sahip, antioksidan özelliği gösteren bir enzimdir [6, 7].

Paraoksonaz enziminin antioksidan ve detoksifikasyon özelliğinden dolayı son yıllarda bu enzim üzerinde çok yoğun çalışmalar yapılmaya başlanmıştır [8-10]. Yapılan çalışmalar, insan serum paraoksonaz enziminin geniş bir substrat özgüllüğüne sahip olduğunu göstermiştir. Aktivite ölçümlerinde değişik substratlar kullanılırken en çok tercih edileni paraoksandır. $[6,11,12]$. İnsan serum paraoksonaz enzimi yüksek oranda saflaştırılmış ve enzimin bazı özellikleri belirlenmiştir [13, 14]. Saflaştırılmış enzim üzerinde yapılan çalışmalar, enzimin üç tane sistein rezidüsü ihtiva eden, 355 aminoasitten meydana geldiğini göstermişstir [15]. Bu sistein rezidülerinin ikisi disülfit köprüsü ile bağlı bir tanesinin de serbest olduğu tespit edilmiştir. Ayrıca inhibitör ve yönlendirilmiş mutagenez çalışmaları ve aktivitesi için $\mathrm{Ca}^{+2}$ a bağımlılığı dikkate alınarak enzimin aktif bölgesinde Triptofan, Asparagin ve glutamin rezidülerinin bulunduğu gösterilmiştir [12, 16-18].

PON1'in aktivitesinin azalmasiyla birlikte ateroskleroz ve organofosfat toksisitesi riski olduğu kabul edilmiş ve bu nedenle, PON1'i etkileyen faktörlerin net bir şekilde anlaşılması gerekmiştir. Literatürde, PON1 enziminin biyolojik fonksiyona etki mekanizmalarını anlamak için bazı önemli çalışmalar yapılmıştır [19, 20]. Literatürde 
ticari olarak temin edilebilen çeşitli ilaçlar, bazı metal iyonları, kumarin türevleri ve pestisitlerin inhibisyon çalışması bildirilmiştir. Tüm bu nedenlerden dolayı, PON'lar yoğun araştırma konusu haline gelmiştir [21-26].

Tiyo taç eterlerin metal iyonlarına karşı olan ilgileri bilim adamlarının dikkatini çekmiştir. 1969'da Rosen ve Busch 14S4'ü sentezlediler ve bunun nikel(II) kompleksini hazırladılar [27]. Oksijen içeren taç eterlerin özellikle katyonlarla koordine davranışı yoğun olarak çözeltiden alkali metal iyonlarını izole etmek ve bağlamak için kullanıldı [28, 29]. Azot ve kükürt donör atomları içeren halkalı bileşikler onların ağır geçiş metal iyonlarıyla yüksek afinite göstermesi ve onların seçiciliği donör atom ve halka boyutunu değiştirerek kolayca akort edilebilir olması oldukça ilgi çekicidir. O,N,S-donör taç eterler ilginç bir bileşik sınıfı oluşturur ki yumuşak metal katyonlar için seçici ekstraktant ve bazı enzimlerin aktivitesi için bir model olarak kullanılmıştır [30-32].

Bu çalışmada, Çiçek ve ark. tarafindan sentezlenen 7,13-dithio-1,4,10-trioksasiklo pentadekan (DT-15-Crown-5) [33] bileşiğinin PON1 enzimi üzerindeki inhibisyon etkisi in vitro şartlar altında araştırılıp $\mathrm{IC}_{50}$ değeri hesaplanmıştır.

\section{Deneysel çalışmalar}

\subsection{Inhibitör olarak kullanılan tiyo taç eter}

$\mathrm{Bu}$ çalışmada kullanılan tiyo taç eter halka kapama yöntemiyle $\mathrm{S}_{\mathrm{N}}{ }^{2}$ mekanizmasına göre azot atmosferinde ve sezyum karbonat (baz) varlı̆̆ında reaksiyona girdirilerek sentezi gerçekleştirilmiştir.

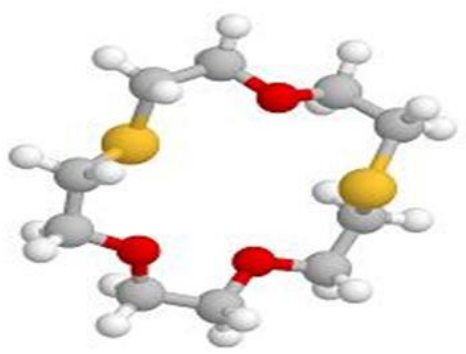

Şekil 1. 7,13-dithio-1,4,10-trioksasiklopentadekan (DT-15-Crown-5).

\subsection{PON1 enziminin insan kanından hidrofobik etkileşim kromatografisi ile saflaştırılması}

İnsan kan serrumu, $40 \mathrm{~mL}$ taze insan kanından izole edildi ve kuru bir tüpe kondu. Kan örnekleri 3000 rpm'de 15 dakika santrifüj edildi ve serum uzaklaştırıldı. İlk olarak, serum paraoksonaz, amonyum sülfat çöktürmesiyle (\% 60-80) izole edildi [34]. Çökelti, 20 dakika boyunca 15000 rpm'de santrifüjlenerek topland 1 ve $100 \mathrm{mM}$ Tris HC1 tamponunda ( $\mathrm{pH} \mathrm{8.0)}$ yeniden çözündürüldü. Sonra, insan serum paraoksonaz enzimini daha önce grubumuz tarafindan sentezlenen Sepharose 4B-L-tirozin-1-naftilamin hidrofobik jeli ile saflaştırıldı [34]. Kolon, $1 \mathrm{M}$ amonyum sülfat içeren $0.1 \mathrm{M} \mathrm{Na}_{2} \mathrm{HPO}_{4}$ tamponu ( $\mathrm{pH} 8.00$ ) ile dengelenmiştir. Elüsyonu ise amonyum sülfatlı ve amonyum sülfatsız $0,1 \mathrm{M} \mathrm{Na}_{2} \mathrm{HPO}_{4}$ tamponu $(\mathrm{pH} 8.00)$ kullanılarak amonyum sülfat gradyanı ile elüe edildi. 


\subsection{PON1 enziminin aktivite tayini}

PON1 enziminin paraoksona karşı aktivitesi, Gan ve arkadaşları tarafından tarif edilen yöntemle spektrofotometrik olarak ölçüldü [8].

\subsection{Inhibitörün [IC 50$]$ de ğerlerinin bulunması}

İnhibitörlerin $\mathrm{IC}_{50}$ değerlerini bulmak için, farklı konsantrasyonlarda taç eter reaksiyon ortamına ilave edilerek aktivite ölçümleri yapıldı. İnhibitörsüz ortamda bulunan enzim aktivitesi \%100 aktivite olarak kabul edilerek, inhibitörlü ölçümlerin \% aktiviteleri hesaplandı ve \% Aktivite - [I] grafiği çizildi (Şekil 2).

\section{Sonuçlar ve tartışma}

Hidrofobik etkileşim kromatogrofisi ile saflaştırılan PON1 enziminin saflık kontrolü SDS-PAGE ile yapılmıştır. Şekil 2'deki inhibisyon grafiği kullanılarak inhibitör olarak kullandığımız bileşiğin [ $\mathrm{IC}_{50}$ ] değeri 22,62 $\mu \mathrm{M}$ olarak hesaplanmıştır.

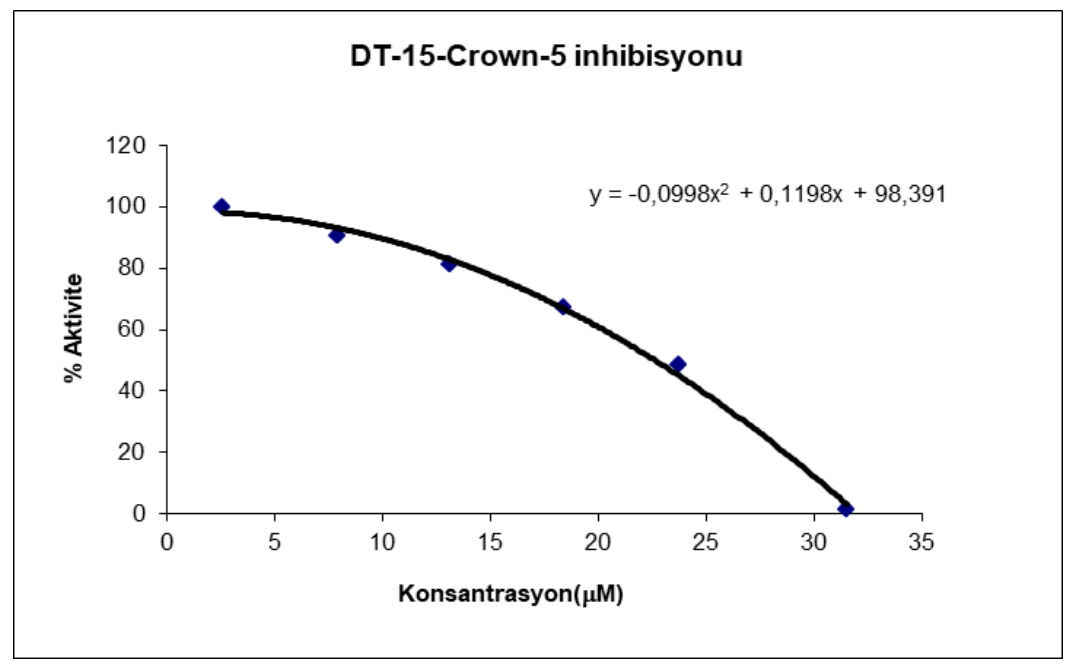

Şekil 2. IC I0 $_{50}$ grafiği.

PON1 enziminin inhibisyonu için literatürde bazı inhibitörlerden bahsedilmiştir. Karatas ve arkadaşları tarafından yapılan bir çalışmada bazı kumarin ve benzoksazinonlar PON1 enziminin aktivitesini önemli derecede düşürdüğü görülmüştür [35]. Bunlara ek olarak bazı anestezikler, kalsiyum kanal blokerleri, bazı metal iyonları ve bazı pestisitlerin söz konusu enzimi inhibe ettikleri belirtilmiştir [36-39].

Bazı tiyo taç eterlerin karbonik anhidraz ve polifenol oksidaz enzimlerini inhibe ettiği literatürde belirtilmiştir [40-43]. Tiyo taç eterlerin metal iyonlarına olan ilgisinden dolayı söz konusu çalışmada inhibitör olarak kullandığımız bileşik, biyomolekül olan PON1 enziminin aktif bölgesindeki $\mathrm{Ca}^{2+}$ iyonu ile etkileşime girerek inhibe ettiği söylenebilir.

Çalışmamızda kullandığımız DT-15-Crown-5, Şekil 3.'de gösterildiği gibi PON1 enziminin aktif bölgesinde kofaktör olarak bulunan $\mathrm{Ca}^{2+}$ ile etkileşime girdiğinden enzimi inhibe ettiği deneyle ispatlanmıştır. Bu inhibitör özelliği ile DT-15-Crown-5 ileri çalışmalarda farmakolojik ajan olarak kullanılması mümkündür. 

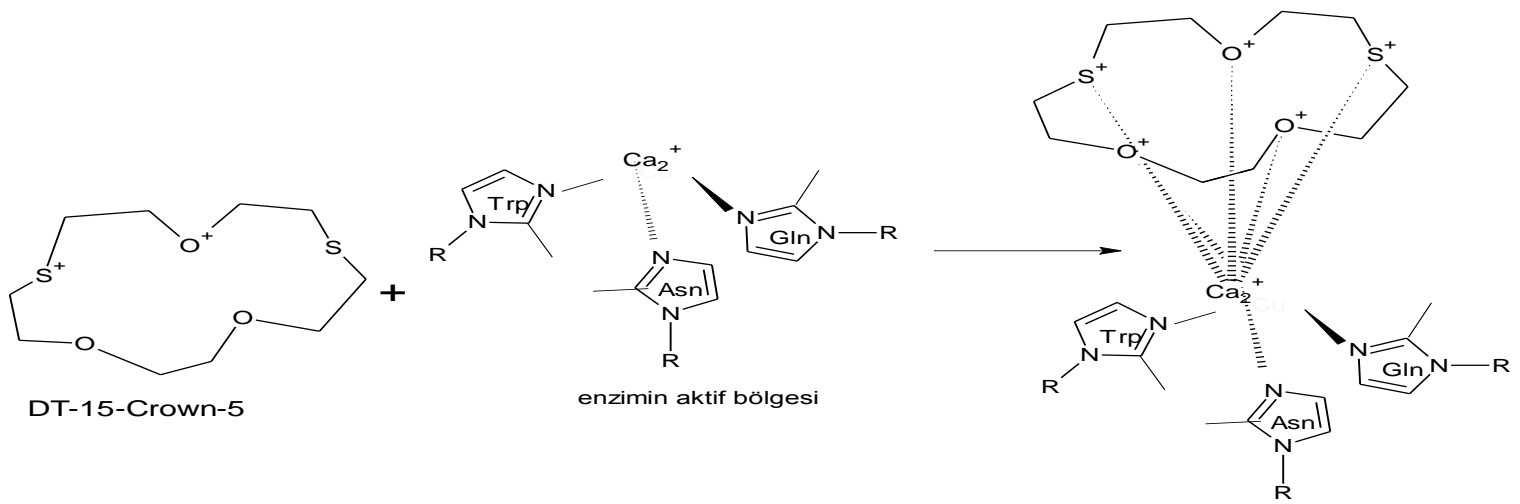

Şekil 3. DT-15-Crown-5 inhibitörü ile PON1 enziminin etkileşim mekanizmas1.

\section{Kaynaklar}

[1] Broomfield, C.A., Ford, K.W., Hydrolyses of nerve gases by plasma enzymes, Proceedings of the 3rd International Meeting on Cholinesterases, La Grande-Motte, 161, 65, (1991).

[2] Davies, H.C., Richter, R.J., Keifer, M., Broomfield, C.A., Sowalla, J., Furter, C.I., The effect of the human serum paraoxonase polymorphism is reversed with diazoxon, soman and sarin, Nature Genetics, 14, 334, (1996).

[3] Jakubowski, H., Calcium-dependent human serum homocysteine thiolactone hdyrolase. A protective mechanism against protein N-homocysteinylation, J.

Biol. Chem., 275, 3957, (2000).

[4] Kitchen, B.J., Masters, C.J. and Winzor, D.J., Effects of lipid removal on the molecular size and kinetic properties of bovine plasma arylesterase, Biochem $\mathbf{J}$, 135, 93, (1973).

[5] Mazur, A., An enzyme in animal tissue capable of hydrolyzing the phosphorusfluorine bond of alkyl fluorophosphates, J. Biol. Chem., 164, 271-289, (1946)

[6] Aldridge, W.N., Serum esterases I: two types of esterases (A and B) hydrolysing p-nitrophenyl acetate propionate and butyrate and a method their determination, Biochem J., 53,110-117, (1953).

[7] Aldridge, W.N., Serum esterases II: an enzyme hyrolysing diethyl p-nitrophenyl phosphate (E600) and its identitiy with the A-esterase of mamalian sera, Biochem. J., 53, 117-124, (1953)

[8] Gan, K.N., Smolen, A., Eckerson, H.W., La Du, B.N., Purification of human serum paraoxonase/arylesterase. Evidence for one esterase catalyzing both activities, Drug Metab. Dispos., 19, 100-106, (1991).

[9] Sorenson RC., Primo-Parmo SL., Kuo CL., Adkins S., Lockridge O. and La Du BN., Reconsideration of the catalytic center and mechanism of mammalian paraoxsonase/arylesterase, Proc. Natl. Acad. Sci. USA, 92, 7187-7191, (1995).

[10] Sorenson RC., Aviram, M., Bisgaier, C.L., Billecke, S., Hsu, C., La Du, B.N., Properties of retained $\mathrm{N}$-terminal hydrophobic leader sequence in human serum paraoxonase/arylesterase, Chem. Biol. Interact., 119-120, 243-249, (1999).

[11] Main, A.R., The role of A- esterase in the acute toxicity of paraoxon, TEPP and parathion, Can. J. Biochem. Physiol., 34, 197-216, (1956).

[12] Aviram, M., Hardak, E., Vaya, J., Mahmood, S., Milo, S., Hoffman, A., Billecke, S., Draganov, D. and Rosenblat, M., Human serum paraoxonases (PON1) Q and R selectively decrease lipid peroxides in human coronary and 
carotid atherosclerotic lesions: PON1 esterase and peroxidase-like activities, Circulation, 101, 2510, (2000).

[13] Azarsız, E. and Sözmen, E.Y., Paraoksonaz ve Klinik Önemi, Türk Biyokimya Dergisi, (2000)

[14] La Du, B.N., Pharmagenetics of drug Metabolism, Pergamon, Elmsford, NY, 51-91, (1992)

[15] Rodrigo, L., Gil, f., Hernandez,A.F., Pla, a., Identification of two rat liver proteins with paraoxonase activity: biochemical evidence for the identitiy of paraoxonase and arylesterase, Chem. Biol. Interact. 119-120,263-275, (1999).

[16] Sozmen, B., Delen, Y., Girgin, F.K., Sözmen, E.Y., Catalase and paraoxonase in hypertensive type 2 diabetes mellitus: correlation with glycemic control, Clinical Biochemistry, 32,423-427, (1999).

[17] Rolls, Bj, Effects of Intense Sweeteners on Hunger, Food-Intake, and BodyWeight, American Journal of Clınıcal Nutritıon, 53, 872-878, (1991).

[18] Zarate, F.M., Schulwitz, S.E., Stevens, K.J., Venables, B.J., Bioconcentration of triclosan, methyl-triclosan, and triclocarban in the plants and sediments of a constructed wetland source, Chemosphere, 88, 323-329, (2012).

[19] Billecke, S., Draganov, D., Counsell, R., et al., Human serum paraoxonase (PON1) isozymes Q and R hydrolyze lactones and cyclic carbonate esters, Drug Metab Dispos, 28, 35-41, (2000).

[20] Harel, M., Aharoni, A., Gaidukov, L., et al., Structure and evolution of the serum paraoxonase family of detoxifying and anti-atherosclerotic enzymes, Nat Struct Mol Biol., 11, 412-419, (2004).

[21] Kockar, F., Sinan, S., Yildirim, H., Arslan, O., Differential effects of some antibiotics on paraoxonase enzyme activity on human hepatoma cells (Hep62) in vitro, J. Enzyme Inhib Med Chem, 25, 715-719, (2010).

[22] Erzengin, M., Basaran, I., Cakir, U., et al., In vitro inhibition effects of some dihydroxycoumarin compounds on purified human serum paraoxonase I (PON1), Appl Biochem Biotechnol, 168, 1540-1548, (2012).

[23] Senturk, M., Ekinci, D., Alici, H.A., Beydemir, S., Paraoxonase-1, an organophosphate detoxifier and cardioprotective enzyme is inhibited by anasthetics: an in vitro and in vivo insight, Pest Biochem Physiol, 11, 206-211, (2011).

[24] Turkes C, Soyut H, Beydemir S. Effect of calcium channel blockers on paraoxonase-1 (PON1) activity and oxidative stress, Pharmacol Rep, 66,74-80, (2014).

[25] Pla, A., Rodrigo, L., Hernandez, A.F., et al., Effect of metal ions and calcium on purified PON1 and PON3 from rat liver, Chem Biol Interact, 167, 63-70, (2007).

[26] Gencer, N., Arslan, O., In vitro effects of some pesticides on PON1Q192 and PON1R192 isoenzymes from human serum, Fresen Environ Bull, 20, 590-596, (2011).

[27] Black, D.St.C., McLean, I.A., Tetrahedron Lett., 39, 61, (1969).

[28] Izatt, R.M., Pawlak, K., Bradshaw, J.S., Bruening, R.L., Chem. Rev., 91, 1721, (1991).

[29] Craig, A.S.. Kataky, R., Matthews, R.C., Parker, D., Ferguson, G., Lough, A., Adams, H., Bailey, N., Schneider, H., J. Chem.Soc., 2, 1523, (1990).

[30] Bradshaw, J.S., Izatt, R.M., Acc. Chem. Res., 30, 338, (1997).

[31] Krylova, K., Kulatilleke, C.P., Hegg, M.J., Salhi, C.A.,. Ochrymowycz, L.A, Rorabacher, D.B., Inorg. Chem., 38, 4322, (1999). 
[32] van de Water, L.G.A., Driessen, W.L., Glenny, M.W., Reedijk, J., Schröder M., React. Funct. Polym., 51, 33, (2002).

[33] Çiçek, B., Yildiz, A., Synthesis Metal Ion Complexation and Computational Studies of Thio Oxocrown Ethers, Molecules, 16, 8670-83, (2011).

[34] Sinan, S., Kockar, F., Arslan, O., Novel purification strategy for human PON1 and inhibition of the activity by cephalosporin and aminoglikozide derived antibiotics, Biochimie, 88, 565-574, (2006).

[35] Karataş, M.O., Uslu, H., Alıc1, B., Gökçe, B., Gencer, N., Arslan, O., Some coumarins and benzoxazinones as potent paraoxonase 1 inhibitors, J Enzyme Inhib Med Chem., 31, 1386-1391, (2016).

[36] Senturk, M., Ekinc,i D., Alici, H.A., Beydemir, S., Paraoxonase-1, an organophosphate detoxifier and cardioprotective enzyme is inhibited by anasthetics: an in vitro and in vivo insight, Pest Biochem Physiol, 11, 206-211, (2011).

[37] Turkes, C., Soyut, H., Beydemir, S., Effect of calcium channel blockers on paraoxonase-1 (PON1) activity and oxidative stress, Pharmacol Rep 66, 74-80, (2014).

[38] Pla, A., Rodrigo, L., Hernandez, A.F., et al., Effect of metal ions and calcium on purified PON1 and PON3 from rat liver, Chem Biol Interact, 167, 63-70, (2007).

[39] Gencer, N., Arslan, O., In vitro effects of some pesticides on PON1Q192 and PON1R192 isoenzymes from human serum, Fresen Environ Bull, 20, 590-596, (2011).

[40] Ergün, A., Çiçek, B., Bazı makrohalkalı tiyocrown eterlerin polifenol oksidaz enzimi üzerindeki inhibisyon etkilerinin araştırılması, Balıkesir Üniversitesi Fen Bilim Enstitüsü Dergisi, 20, 1-8, (2018).

[41] Akkemik, E., Çalışır, Ü., Çiçek, B., İnsan karbonik anhidraz I,II izoenzim aktiviteleri üzerine bazı tiyocrown eterlerin etkisi, Balıkesir Üniversitesi Fen Bilim Enstitüsü Dergisi,;19, 192-199, 2017.

[42] Çiçek, B., Ergün, A., Gencer, N., Synthesis and Evaluation in vitro Effects of Some Macrocyclic Thiacrown Ethers on Erythrocyte Carbonic Anhydrase I and II, Asian Journal of Chemistry, 24, 3729-3731, (2012).

[43] Akkemik, E., Çiçek, B., Camadan, Y., Çalışır, U., Onbasioglu, Z., The determination of the carbonic anhydrases activators in vitro effect of mixed donor crown ethers, Journal of Biochemical and Molecular Toxicology, 32, 3, (2018). 